\title{
PENGARUH PENDEKATAN KOMUNIKATIF BERBASIS TALKING STICK TERHADAP KEMAMPUAN LITERASI DINI ANAK
}

\author{
Ni Md. Malini Mas Udayani Rangkan ${ }^{1}$, I Nyoman Jampel ${ }^{2}$, Putu Aditya Antara ${ }^{3}$ \\ 1,3 Jurusan Pendidikan Guru Pendidikan Anak Usia Dini \\ 2 Jurusan Teknologi Pendidikan \\ Fakultas IImu Pendidikan \\ Universitas Pendidikan Ganesha \\ Singaraja, Indonesia
}
e-mail: malinimas97@gmail.com¹, jampel@undiksha.ac.id ${ }^{2}$, putuaditya.antara@undiksha.ac.id ${ }^{3}$

\begin{abstract}
Abstrak
Penelitian ini bertujuan untuk mengetahui perbedaan kemampuan literasi dini anak, antara anak yang mendapat pembelajaran menggunakan pendekatan komunikatif berbasis talking stick dengan anak yang mendapat pembelajaran menggunakan pendekatan konservatif pada anak kelompok B Taman Kanak-Kanak Gugus Melati Kecamatan Denpasar Utara tahun pelajaran 2017/2018. Penelitian ini termasuk penelitian eksperimen semu (quasi eksperimen) dengan rancangan non-equivalent control group design. Populasi penelitian ini adalah seluruh anak kelompok B Taman Kanak-Kanak Gugus Melati berjumlah 510 anak. Sampel penelitian ditentukan dengan teknik simple random sampling. Adapun sampel penelitian ini adalah kelompok B1 TK Gita Maharani berjumlah 28 anak sebagai kelompok eksperimen dan kelompok B2 TK Aisyiyah Bustanul Athfal 5 berjumlah 22 anak sebagai kelompok kontrol. Data hasil kemampuan literasi dini dikumpulkan dengan teknik observasi menggunakan instrument lembar observasi kemampuan literasi dini. Data yang diperoleh dianalisis menggunakan statistik deskriptif dan statistik inferensial (uji-t). Berdasarkan hasil uji-t diperoleh $t_{\text {hitung }}=12,597$ dan dengan taraf signifikan $5 \%, \mathrm{dk}=48$ diperoleh $t_{\text {tabel }}=2,021$. Maka, $\mathrm{t}_{\text {hitung }}>$ $t_{\text {tabel, }}$, sehingga $\mathrm{H}_{0}$ ditolak dan $\mathrm{H}_{\mathrm{A}}$ diterima. Dengan demikian, dapat ditarik kesimpulan bahwa terdapat perbedaan secara signifikan kemampuan literasi dini anak, antara anak yang mendapat pembelajaran menggunakan pendekatan komunikatif berbasis talking stick dengan anak yang mendapat pembelajaran menggunakan pendekatan konservatif pada anak kelompok B Taman Kanak-Kanak Gugus Melati Kecamatan Denpasar Utara tahun pelajaran $2017 / 2018$.
\end{abstract}

Kata-kata Kunci: anak, kemampuan literasi dini, pendekatan komunikatif berbasis talking stick

\begin{abstract}
This study aims to determine differences in the ability of children's early literacy, between children who received learning using a communicative approach based on talking stick with children who received learning using a conservative approach based on talking stick in children of group B of Gugus Melati Kindergarten North Denpasar District academic year 2017/2018. This study included a quasi-experiment with a non-equivalent control group design. The population of this study is the children of group B Gugus Melati Kindergarten. The total amount of the children is 510 . The sample is determined by simple random sampling technique. The sample is B1 TK Gita Maharani group of 28 children as the experiment group and B2 TK Aisyiyah Bustanul Athfal 5 group of 22 children as the control group. The data is collected using observation technique as well as the observation sheet as the instrument. The data obtained is analyzed using descriptive statistics and inferential statistics ( $T$-test). The $T$-test result shows that $t_{- \text {nitung }}=12.597$ and with a significant level of $5 \%, d k=48$ obtained $t_{\text {tabel }}=2.021$. Thus, $t_{\text {hitung }}>t_{\text {tabel }}$, moreover, $\mathrm{HO}$ is rejected and HA is accepted. In conclusion, there are significant differences in early literacy ability of children, between children who received learning using a
\end{abstract}


communicative approach based on talking stick with children who received learning using a conservative approach in children of group B of Gugus Melati District Kindergarten North Denpasar academic year 2017/2018.

Keywords: children, communicative approach based on talking stick, early literacy ability

\section{PENDAHULUAN}

Bahasa adalah alat untuk berkomunikasi. "Bahasa merupakan aspek perkembangan yang berperan penting dalam kehidupan manusia" (Ambara, dkk., 2014:34). Bahasa dapat membantu mengorganisasikan pikiran dan membantu dalam mempelajari sesuatu (Izzaty, 2017:82). Bahasa bagi anak adalah alat komunikasi untuk menyampaikan keinginan, pikiran, harapan, permintaan untuk dirinya sendiri (Direktorat Pendidikan Anak Usia Dini, 2010:4). Bahasa merupakan landasan anak untuk mempelajari pengetahuan lain. Sebelum anak belajar pengetahuanpengetahuan lain, anak perlu menggunakan bahasa agar dapat memperoleh pemahaman dengan baik. Direktorat Pendidikan Anak Usia Dini (2010:3) menyatakan "dengan berbahasa, anak dapat mengembangkan kemampuan dalam bidang pengucapan bunyi, menulis, membaca yang sangat mendukung kemampuan keaksaraan yang lebih tinggi". Dengan kata lain, perkembangan bahasa merupakan dasar dari kemampuan literasi dini.

"Literasi dini berkaitan dengan kegiatan membaca dan menulis bagi anak usia dini" (Inten, 2017:25). Department of Education and Child Development (2013) menyatakan, "kemampuan literasi mencakup pengetahuan, keterampilan, dan sikap yang dikembangkan anak dalam kaitannya dengan membaca dan menulis sepanjang masa anak usia dini, mulai sejak lahir dan sebelum mulainya pengajaran membaca dan menulis konvensional (biasanya di sekolah)". Mustafa (dalam Inten, dkk., 2016:72) menegaskan literasi dini merupakan proses membaca dan menulis yang bercirikan seperti demonstrasi baca-tulis, kerjasama yang interaktif antara orang tua dan anak, berbasis kepada kebutuhan sehari-hari dan dengan cara pengajaran minimal tetapi langsung. "Ciri khas dari literasi dini adalah pembelajaran secara informal, yaitu anak-anak jangan merasa sedang belajar" (Permatasari, dkk., 2017:22). Berkaitan dengan kemampuan literasi, Marie Clay merupakan sosok yang dikenal sebagai pakar baca-tulis (Seefeldt\&Barbara, 2008:329). Clay (dalam Konstantellou, 2009:65) menyatakan bahwa saat anak terlibat dalam kegiatan membaca dan menulis, dapat merakit kompetensi perseptual yang membantu mereka memecahkan masalah.

Neuman, dkk. (dalam Seefeldt \& Barbara, 2008:336-337) menegaskan bahwa bagi anak-anak usia lima tahun, tujuan baca tulis ialah mengembangkan konsep-konsep dasar huruf cetak dan mulai terlibat dan bereksperimen dengan membaca dan menulis. Neuman, dkk. (dalam Seefeldt \& Barbara, 2008:337) menyebutkan terdapat beberapa cara untuk melaksanakan tujuan baca tulis. Cara-cara yang dapat dilakukan untuk melaksanakan tujuan baca tulis bagi anak usia lima tahun meliputi, a) menikmati yang sedang dibacakan dan menuturkan kembali ceritacerita naratif sederhana atau teks informasi, b) menggunakan bahasa deskriptif untuk menjelaskan dan menyelidiki, c) mengenali huruf-huruf dan bunyi huruf-huruf, d) memperlihatkan keakraban dengan bunyibunyi berima dan awal, e) mengerti orientasi kiri ke kanan dan atas ke bawah dan konsep akrab dari huruf cetak, f) menyesuaikan kata-kata yang diucapkan dengan kata-kata yang ditulis, g) mulai menulis huruf-huruf abjad dan beberapa kata yang sering digunakan.

Kunci penting kemampuan literasi dini anak meliputi kesadaran fonemik, pemahaman huruf cetak, dan pengetahuan tentang huruf (Seefeldt \& Barbara, 2008:323). Antara (2017:51) menyatakan, "fonem dalam bahasa Indonesia terdiri atas 
vokal dan konsonan". Vokal adalah bunyi ujaran yang tidak mendapatkan rintangan saat dikeluarkan dari paru-paru. Vokal dibagi menjadi dua, yaitu vokal tunggal (monoftong) yang meliputi a, i, u, e, o dan vokal rangkap (diftong), yang meliputi ai, au, oi. Konsonan adalah bunyi ujaran yang dihasilkan paru-paru dan mengalami rintangan saat keluarnya. Contoh konsonan antara lain $p, b, m, f, v, t, d, n, c, j, k, g, h$. Pemahaman huruf cetak berkaitan dengan pengalaman yang berulang dengan huruf cetak sehingga anak-anak menjadi mengerti fungsi huruf cetak dihubungkan dengan membaca (Seefeldt \& Barbara, 2008:328). Pengetahuan tentang huruf cetak mengacu pada aspek mengenal huruf, membuat huruf, dan belajar asosiasi bunyi-huruf (Seefeldt \& Barbara, 2008:330).

Merujuk pada data statistik UNESCO, "Indonesia berada di peringkat 60 dari total 61 negara dengan tingkat literasi rendah" (CNN Indonesia, 2017). Berdasarkan data tersebut, dapat dilihat bahwa minat membaca dan menulis di Indonesia masih rendah. "Salah satu faktor yang menyebabkan rendahnya literasi di Indonesia adalah belum ada kebiasaan membaca yang ditanamkan sejak dini" (CNN Indonesia, 2017). Lisnawati (dalam Antara News, 2014) menyatakan orang tua maupun pendidik diharapkan menekankan kepada anak bahwa membaca buku dan bermain terkait literasi perlu lebih dimanfaatkan sebagai aktivitas yang memberi pengalaman yang menyenangkan. Hal itu penting dilakukan untuk mengembangkan literasi awal agar permasalahan kurangnya minat dan kebiasaan membaca serta menulis dapat diatasi (Lisnawati dalam Antara News, 2014). Maka dari itu, kemampuan literasi penting dikembangkan pada masa kanakkanak sebagai pondasi dalam membangun pengetahuan awal anak untuk menjadi pembaca dan penulis yang kompeten.

Berdasarkan hasil observasi yang dilakukan di Gugus Melati Kecamatan Denpasar Utara, ditemukan permasalahan terkait dengan kemampuan literasi dini. Hasil observasi menunjukkan bahwa permasalahan terkait dengan kemampuan literasi dini diantaranya, a) beberapa anak masih kesulitan dalam membedakan huruf ketika guru mengacak susunan huruf. Misalnya membedakan huruf $b$ dengan $d, m$ dengan $n, p$ dengan $q$. b) Pada saat anak diminta menuliskan huruf, anak terlihat terbalik menuliskan huruf. Misalnya ketika anak menulis huruf $\mathrm{c}$ ditulis $\mathrm{o}$, huruf $\mathrm{d}$ ditulis $b$, huruf e ditulis $\ominus$, huruf $s$ ditulis a serta anak tidak mengetahui cara menulis huruf q. c) Anak juga masih kesulitan dalam membuat asosiasi bunyi huruf. Misalnya, ketika anak diminta melengkapi kata ubi. Anak justru menyusunnya menjadi kata udi.

Hasil wawancara dengan guru kelompok B taman kanak-kanak gugus melati juga menyatakan bahwa sebagian besar anak-anak memang mempunyai permasalahan terkait membedakan huruf, menuliskan huruf dan membuat asosiasi bunyi huruf. Permasalahan terkait kemampuan literasi dini yang terjadi pada anak kelompok B Taman Kanak-kanak Gugus Melati disebabkan karena setiap anak memiliki kemampuan yang berbedabeda. Maka, terdapat anak yang cepat dalam menerima pembelajaran baca tulis dan terdapat anak yang lambat dalam menerima pembelajaran baca tulis. Selain itu, guru dalam pembelajaran dikelas lebih mengarah pada teacher center. Pada saat memberikan tugas terkait literasi dini, guru hanya menggunakan majalah. Sehingga, proses pembelajaran literasi dini yang diterapkan guru kurang sesuai dengan ciri khas literasi dini yaitu, membuat anak-anak jangan merasa sedang belajar.

Melihat permasalahan yang ditemui pada anak kelompok B Taman Kanak-Kanak Gugus Melati Kecamatan Denpasar Utara, maka perlu dilakukan perbaikan dan pembaharuan proses pembelajaran untuk meningkatkan kemampuan literasi dini anak. Salah satu alternatif dalam perbaikan pembelajaran yang sesuai dengan permasalahan tersebut adalah menggunakan suatu pendekatan. "Pendekatan pembelajaran yang dipilih untuk pengaturan kelas menentukan corak detail aktivitas pembelajaran tersebut" (Rafli \& Ninuk, 2015:7). Memilih pendekatan pembelajaran yang sesuai dengan karakteristik anak dapat membuat kegiatan belajar mengajar berjalan dengan efektif (Rafli \& Ninuk, 2015:7). Berbagai jenis 
pendekatan pembelajaran dapat digunakan untuk meningkatkan kemampuan literasi dini anak. Adapun pendekatan-pendekatan dalam pembelajaran yang telah ditetapkan oleh International Baccalaureate (dalam Huda, 2013:185) adalah pendekatan organisasional, pendekatan kolaboratif, pendekatan komunikatif, pendekatan informatif, pendekatan reflektif, serta pendekatan berpikir dan berbasis masalah. Berdasarkan teori-teori yang ada dalam masing-masing pendekatan tersebut yang paling cocok untuk meningkatkan kemampuan literasi dini anak adalah pendekatan komunikatif.

$$
\text { Huda (2013:215) menyatakan }
$$

"pendekatan pembelajaran yang berbasis komunikasi memungkinkan anak untuk mampu membaca dan menulis dengan baik, belajar dengan orang lain, menggunakan media, menerima informasi dan menyampaikan informasi". Mukhlis (dalam Kompasiana, 2017) menegaskan, salah satu cara untuk mengembangkan literasi dini adalah membaca dengan keras dan banyak berbicara. Hal ini sejalan dengan pembelajaran menggunakan pendekatan komunikatif yang didasarkan pada tujuan membaca dan diarahkan pada penggunaan bahasa dalam kehidupan sehari-hari (Rahim, 2007:32). Huda (2013:215) menyatakan, "pendekatan komunikatif tidak dapat diterapkan tanpa adanya metode aplikatif yang mendukung". Salah satu metode aplikatif yang termasuk ke dalam pendekatan komunikatif dan digunakan dalam pembelajaran adalah metode talking stick (tongkat berbicara). Metode talking stick (tongkat berbicara) dipilih, karena metode ini cocok digunakan untuk semua kelas dan semua tingkatan umur (Huda, 2013 :225). Huda (2013:224) menyatakan, "talking stick merupakan metode pembelajaran dengan bantuan tongkat".

Penelitian ini memiliki tujuan untuk mengetahui perbedaan secara signifikan kemampuan literasi dini anak, antara anak yang mendapat pembelajaran menggunakan pendekatan komunikatif berbasis talking stick dengan anak yang mendapat pembelajaran menggunakan pendekatan konservatif pada anak kelompok B Taman Kanak-Kanak Gugus
Melati Kecamatan Denpasar Utara tahun pelajaran 2017/2018.

\section{METODE}

Penelitian ini merupakan jenis penelitian eksperimen semu (quasi eksperimen). "Eksperimen semu (quasi eksperimen) adalah jenis komparasi yang membandingkan pengaruh pemberian suatu perlakuan pada suatu objek serta melihat besar pengaruh perlakuannya" (Nurdin, 2012:27). "Pada proses penelitian quasi eksperimen tidak dilakukan pengacakan siswa dalam penempatan ke dalam kelompok eksperimen dan kontrol" (Nurdin, 2012:27). Sugiyono (2017:77) menegaskan "eksperimen semu (quasi eksperimen) memiliki kelompok kontrol, tetapi tidak dapat berfungsi sepenuhnya untuk mengontrol variabel-variabel luar yang mempengaruhi pelaksanaan eksperimen".

Penelitian ini menggunakan rancangan non-equivalent control group design. Desain penelitian ini dipilih karena pada rancangan ini subjek penelitian atau partisipan penelitian tidak dipilih secara acak untuk dilibatkan dalam kelompok eksperimen dan kelompok kontrol (Setyosari, 2016:210). Dalam rancangan ini ada dua subjek. Satu kelompok mendapat perlakuan (kelompok eksperimen) dan satu kelompok sebagai kelompok kontrol. Keduanya memperoleh prates dan pascates. Pelaksanaan penelitian ini terdiri dari tiga tahap yaitu, (1) tahap persiapan, (2) tahap pelaksanaan, (3) tahap akhir (tahap akhir eksperimen).

Populasi penelitian adalah keseluruhan, gejala/satuan yang ingin diteliti. Dalam penelitian ini yang menjadi populasi yaitu seluruh anak kelompok B Taman Kanak-kanak Gugus Melati Kecamatan Denpasar Utara Tahun Pelajaran 2017/2018 berjumlah 510 anak. Sebelum menentukan sampel terlebih dahulu dilakukan uji kesetaraan dengan menganalisis nilai kemampuan literasi dini anak menggunakan rumus ANAVA $A$. Berdasarkan hasil analisis dengan ANAVA A pada taraf signifikansi $5 \%$, diperoleh nilai $F_{\text {hit }}$ sebesar 0,58 sedangkan nilai $F_{\text {tab }}$ pada $\mathrm{db}_{\text {antar }}=18$ dan $\mathrm{db}_{\mathrm{dal}}=492$ sehingga diperoleh $F_{\text {tabel }}$ sebesar 1,60. Maka terlihat 
$F_{\text {hit }}<F_{\text {tab }}(0,58<1,60)$, sehingga $H_{A}$ ditolak dan $\mathrm{H}_{0}$ diterima. Jadi tidak terdapat perbedaan kemampuan literasi dini anak kelompok B di Gugus Melati Kecamatan Denpasar Utara. Dengan kata lain, kemampuan literasi dini anak kelompok B di Gugus Melati Kecamatan Denpasar Utara setara. Keenam sekolah telah diketahui setara, maka dilakukan pemilihan sampel. Sampel merupakan bagian dari populasi yang ingin diteliti. Dalam menentukan sampel teknik yang digunakan adalah simple random sampling. Berdasarkan hasil simple random sampling diperoleh bahwa kelompok eksperimen yang terpilih adalah anak kelompok B1 TK Gita Maharani yang berjumlah 28 anak. Kelompok kontrol yang terpilih adalah anak kelompok B2 TK Aisyiyah Bustanul Athfal 5 yang berjumlah 22 anak.

Data yang dikumpulkan dalam penelitian ini yaitu data kemampuan literasi dini dengan teknik observasi. Instrumen yang digunakan dalam penelitian ini yaitu lembar observasi kemampuan literasi dini yang berjumlah 19 item. Upaya yang dilakukan untuk mengetahui kualitas isinya, terlebih dahulu dilakukan uji validitas isi (uji pakar) yang dilakukan oleh dua pakar guna mendapatkan kualitas instrument lembar observasi yang baik. Adapun dua pakar dalam hal ini adalah Ibu Ni Ketut Desia

\section{HASIL DAN PEMBAHASAN}

Berdasarkan hasil analisis data dengan analisis statistik deskriptif pada kelompok eksperimen dan kontrol maka diperoleh hasil dari mean, median, modus,
Tristiantari, S.Pd., M.Pd. yang merupakan dosen jurusan Pendidikan Guru Sekolah Dasar pengampu mata kuliah bahasa Indonesia serta Ibu Putu Rahayu Ujianti, M.Psi. berlatar belakang psikologi di jurusan Pendidikan Guru Pendidikan Anak Usia Dini. Setelah melakukan perbaikan butir instrument berdasarkan masukan dari ahli kemudian dilakukan validasi instrumen. menggunakan formula Gregory. Apabila telah selesai melakukan validasi isi dilanjutkan uji validitas butir dan uji reliabilitas instrument. Uji validitas butir dilakukan dengan mengujicobakan instrument ke lapangan kemudian divalidasi menggunakan rumus product moment dan dilanjutkan dengan uji reliabilitas menggunakan rumus alpha cronbach. Jika instrument telah valid dan reliable dilanjutkan dengan penelitian. Data hasil penelitian dianalisis dengan menggunakan statistik deskriptif dan statistik inferensial. Analisis statistik deskriptif digunakan untuk menghitung mean, median, modus, standar deviasi, dan varians pada kelompok eksperimen dan kelompok kontrol. Statistik inferensial yang digunakan adalah uji-t. Sebelum dihitung menggunakan uji-t terlebih dahulu melakukan uji prasyarat yaitu normalitas dan homogenitas varians. Dalam penelitian ini rumus uji-t yang digunakan yaitu polled varians.

Tabel 1. Ringkasan Hasil Statistik Deskriptif Skor Kemampuan Literasi Dini

\begin{tabular}{lcccc}
\hline $\begin{array}{c}\text { Data } \\
\text { Statistik }\end{array}$ & $\begin{array}{l}\text { Kelompok } \\
\text { Eksperimen } \\
\text { (pre-test) }\end{array}$ & $\begin{array}{l}\text { Kelompok } \\
\text { Kontrol } \\
\text { (pre-test) }\end{array}$ & $\begin{array}{l}\text { Kelompok } \\
\text { Eksperimen } \\
\text { (post-test) }\end{array}$ & $\begin{array}{l}\text { Kelompok } \\
\text { Kontrol } \\
\text { (post-test) }\end{array}$ \\
\hline Mean & 27,75 & 27,27 & 50,64 & 32,32 \\
Median & 27,00 & 27,00 & 53,00 & 30,00 \\
Modus & 25 & 25 & 54 & 29 \\
Standar & 4,106 & 3,718 & 5,314 & 4,358 \\
Deviasi & & & 28,238 & 18,989 \\
Varians & 16,861 & 13,827 & 28,50 & \\
\hline
\end{tabular}




\begin{abstract}
Merujuk pada tabel 02 mean kemampuan literasi dini kelompok eksperimen pada data pre-test adalah 27,75 , median sebesar 27,00 , modus sebesar 25, varians sebesar 16,861, dan standar deviasi sebesar 4,106. Apabila ratarata kemampuan literasi dini di konversiakan Ke dalam skala lima berada

pada skor sangat rendah. Hasil mean kemampuan literasi dini kelompok kontrol adalah 27,27 median sebesar 27,00 , modus sebesar 25 , varians sebesar 13,827 dan standar deviasi sebesar 3,718. Apabila ratarata kemampuan literasi dini kelompok kontrol dikonversiakan ke dalam skala lima berada pada kategori sangat rendah.

Ditinjau dari hasil analisis deskriptif kemampuan literasi dini data post-test kelompok eksperimen diperoleh mean 50,64 , median sebesar 53,00 , modus sebesar 54, varians sebesar 28,238 dan
\end{abstract}

standar deviasi sebesar 5,314. Apabila ratarata kemampuan literasi dini kelompok eksperimen dikonversiakan dalam skala lima berada pada kategori sangat tinggi. Selanjutnya, mean kemampuan literasi dini data post-test kelompok kontrol adalah 32,32 median sebesar 30,00 , modus sebesar 29, varians sebesar 18,989 dan standar deviasi sebesar 4,358. Apabila ratarata kemampuan literasi dini kelompok kontrol dikonversiakan ke dalam skala Lima berada pada kategori rendah. Setelah selesai menganalisis data menggunakan statistik deskriptif kemudian dilanjutkan dengan analisis menggunakan statistik inferensial. Sebelum melakukan uji hipotesis terlebih dahulu dilakukan uji prasyarat analisis yaitu uji normalitas dan uji homogenitas. Ringkasan hasil uji normalitas kelas eksperimen dan kontrol pada data pretest dan post-test dapat dilihat pada tabel 2 .

Tabel 2. Ringkasan Hasil Uji Normalitas Sebaran Data Kemampuan Literasi Dini

\begin{tabular}{clccc}
\hline No & $\begin{array}{c}\text { Kelompok Data } \\
\text { Kemampuan Literasi Dini }\end{array}$ & $D_{\text {hitung }}$ & $D_{\text {tabel }}$ & Status \\
\hline 1 & Eksperimen (pre-test) & 0,180 & 0,250 & Normal \\
2 & Kontrol (pre-test) & 0,180 & 0,281 & Normal \\
3 & Eksperimen (post-test) & 0,245 & 0,250 & Normal \\
4 & Kontrol (post-test) & 0,247 & 0,281 & Normal \\
\hline
\end{tabular}

Berdasarkan hasil uji normalitas pada data pre-test kelompok eskperimen diperoleh $D_{\text {hitung }}=0,180$ dengan taraf signifikansi $5 \%$ dan $\mathrm{n}=28$ diperoleh $D_{\text {tabel }}=0,250$, maka dapat dilihat bahwa $D_{\text {hitung }}<D_{\text {tabel }}(0,180<0,250)$. Hal ini menunjukkan sebaran data pada nilai pretest kelompok eksperimen berdistribusi normal. selanjutnya, dari hasil perhitungan uji normalitas pada data pre-test kelompok kontrol diperoleh $D_{\text {hitung }}=0,180$ dengan taraf signifikansi $5 \%$ dan $\mathrm{n}=22$ diperoleh $D_{\text {tabel }}=0,281$, maka $D_{\text {hitung }}<D_{\text {tabel }}$ $(0,180<0,281)$. Ditinjau dari sebaran data pada nilai pre-test kelompok kontrol, maka sebaran data berdistribusi normal.

Merujuk pada tabel 2, hasil perhitungan uji normalitas pada data posttest kelompok eksperimen diperoleh $D_{\text {hitung }}=0,245$ dengan taraf signifikansi $5 \%$ dan $\mathrm{n}=28$ diperoleh $D_{\text {tabel }}=0,250$, maka $D_{\text {hitung }}<D_{\text {tabel }} \quad(0,245<0,250)$. Hal ini menunjukkan sebaran data pada nilai pretest kelompok eksperimen berdistribusi normal. Hasil perhitungan uji normalitas pada data post-test kelompok kontrol diperoleh $D_{\text {hitung }}=0,247$ dengan taraf signifikansi $5 \%$ dan $\mathrm{n}=22$ diperoleh $D_{\text {tabel }}=$ 0,281 , maka $D_{\text {hitung }}<D_{\text {tabel }}(0,247<0,281)$. Dengan demikian sebaran data pada nilai pre-test kelompok kontrol berdistribusi normal.

Normalitas data telah selesai dihitung, kemudian akan diuji homogenitas terhadap varians pasangan antar kelompok eksperimen dan kontrol. Uji yang digunakan adalah uji-F dengan kriteria data homogen jika $F_{\text {hitung }}<F_{\text {tabel. }}$ Ringkasan hasil uji homogenitas varians antar kelompok eksperimen dan kontrol disajikan pada tabel 3. 
Tabel 3. Ringkasan Hasil Uji Homogenitas Kelompok Eksperimen dan Kelompok Kontrol

\begin{tabular}{clccc}
\hline No & $\begin{array}{l}\text { Kelompok Data } \\
\text { Kemampuan Literasi Dini }\end{array}$ & $\mathrm{F}_{\text {hitung }}$ & $\mathrm{F}_{\text {tabel }}$ & Status \\
\hline 1 & $\begin{array}{l}\text { Eksperimen (pre-test) } \\
\text { Kontrol (pre-test) }\end{array}$ & 1,21 & 2,00 & Homogen \\
2 & $\begin{array}{l}\text { Eksperimen (post-test) } \\
\text { Kontrol (post-test) }\end{array}$ & 1,48 & 2,00 & Homogen \\
\hline
\end{tabular}

Merujuk pada tabel 3, hasil perhitungan uji homogenitas data pre-test pada kelompok eksperimen dan kelompok kontrol yaitu, $F_{\text {hitung }}=1,21$ dan $F_{\text {tabel }}$ dengan $\mathrm{dk}$ pembilang $(28-1=27)$ dan $\mathrm{dk}$ penyebut $(22-1=21)$, taraf signifikansi $5 \%$ diperoleh $F_{\text {tabel }}=2,00$. Dengan demikian $F_{\text {hit }}<F_{\text {tabel }}$, sehingga kedua kelompok data pre-test kelompok eksperimen dan kontrol dikategorikan homogen. Berdasarkan hasil perhitungan uji homogenitas data post-test pada kelompok eksperimen dan kelompok kontrol diperoleh $F_{\text {hitung }}=1,48$ dan $F_{\text {tabel }}$ dengan $\mathrm{dk}$ pembilang $(28-1=27)$ dan $\mathrm{dk}$ penyebut $(22-1=21)$ dengan signifikan $5 \%=2,00$. Dengan demikian $F_{\text {hit }}<F_{\text {tabel }}=$
$1,48<2,00$, sehingga kedua kelompok data dikategorikan homogen.

Dilihat dari hasil uji prasyarat analisis data, diperoleh bahwa data kemampuan literasi dini kelompok eksperimen dan kontrol adalah normal dan homogen. Setelah diperoleh hasil dari uji prasyarat analisis data, dilanjutkan dengan pengujian hipotesis penelitian. Pengujian hipotesis tersebut dilakukan dengan menggunakan uji-t dengan rumus polled varians. Kriteria pengujiannya adalah $\mathrm{H}_{0}$ tolak jika $\mathrm{t}_{\text {hitung }}>\mathrm{t}_{\text {tabel }}$ dan $\mathrm{H}_{0}$ terima jika $t_{\text {hitung }}<\mathrm{t}_{\text {tabel }}$. Ringkasan uji hipotesis disajikan pada tabel 4 sebagai berikut.

Tabel 4. Ringkasan Hasil Uji Hipotesis

\begin{tabular}{lccccccc}
\hline $\begin{array}{l}\text { Kemampuan } \\
\text { Literasi Dini }\end{array}$ & $\mathrm{S}^{2}$ & $\bar{X}$ & $\mathrm{~N}$ & $\mathrm{Db}$ & $\mathrm{t}_{\text {hitung }}$ & $\mathrm{t}_{\text {tabel }}$ & Kesimpulan \\
\hline $\begin{array}{l}\text { Kelompok } \\
\text { Eksperimen }\end{array}$ & 28,238 & 50,64 & 28 & & & & \\
\hline $\begin{array}{l}\text { Kelompok } \\
\text { Kontrol }\end{array}$ & 18,989 & 32,32 & 22 & 48 & 12,597 & 2,021 & $\mathrm{H}_{0}$ ditolak \\
\hline
\end{tabular}

Ditinjau dari hasil analisis data menggunakan uji-t diperoleh hasil $t_{\text {hitung }}=12,597$ dan $t_{\text {tabel }}$ dengan $\mathrm{dk}=\left(n_{1}+\right.$ $\left.n_{2}-2\right)=48$, taraf signifikan $5 \%$ diperoleh hasil $t_{\text {tabel }}=2,021$. Hal ini berarti $t_{\text {hitung }}$ lebih besar dari $t_{\text {tabel }}\left(t_{\text {hitung }}>t_{\text {tabel }}\right)$ sehingga $H_{0}$ ditolak atau $\mathrm{H}_{\mathrm{a}}$ diterima. $H_{0}$ ditolak, $H_{A}$ diterima. Dengan demikian dapat disimpulkan bahwa terdapat perbedaan secara signifikan kemampuan literasi dini anak, antara anak yang mendapat pembelajaran menggunakan pendekatan komunikatif berbasis talking stick dengan anak yang mendapat pembelajaran menggunakan pendekatan konservatif pada anak kelompok B Taman Kanak-kanak
Gugus Melati Kecamatan Denpasar Utara tahun pelajaran 2017/2018.

Berdasarkan hasil uji hipotesis data post-test kelompok eksperimen dan kelompok kontrol menunjukkan bahwa terdapat perbedaan yang signifikan kemampuan literasi dini anak, antara anak yang mendapat pembelajaran menggunakan pendekatan komunikatif berbasis talking stick dengan anak yang mendapat pembelajaran menggunakan pendekatan konservatif pada anak kelompok B Taman Kanak-kanak Gugus Melati Kecamatan Denpasar Utara tahun pelajaran 2017/2018. Hal ini dapat dilihat dari hasil $t_{\text {hitung }}$ lebih besar dari $t_{\text {tabel }}$, yaitu $12,597>2,021$. Merujuk pada hasil analisis 
uji hipotesis ini dapat diketahui bahwa pembelajaran pendekatan komunikatif berbasis talking stick lebih baik dibandingkan dengan pembelajaran pendekatan konservatif. Hal tersebut juga didukung dari nilai rata-rata kemampuan literasi dini anak. Nilai rata-rata kemampuan literasi dini anak kelompok eksperimen pada saat post-test diperoleh sebesar 50,64 yang berada pada kategori sangat tinggi, sedangkan nilai rata-rata kemampuan literasi dini anak kelompok kontrol pada saat post-test diperoleh sebesar 32,32 yang berada pada kategori rendah.

Perbedaan nilai pada kelompok eksperimen dan kelompok kontrol ini terjadi karena penerapan pembelajaran antara dua kelompok berbeda. Peningkatan nilai pada kelompok eksperimen ini disebabkan karena pembelajaran pendekatan komunikatif diterapkan menggunakan metode talking stick yang lebih menekankan pada pembelajaran aktif dan menyenangkan dengan cara bermain menggunakan tongkat. Hal ini sejalan dengan ciri khas dalam pembelajaran literasi dini pada anak adalah agar anak jangan merasa sedang belajar (Permatasari, dkk., 2017:22). Christie dan Kathleen (2013:1) juga menegaskan bahwa bermain di tahun-tahun prasekolah memiliki potensi untuk memberikan anak-anak dengan konteks yang sangat menarik dan bermakna untuk mempelajari konsep dan keterampilan keaksaraan awal yang penting.

Huda (2013:215) menyatakan bahwa pendekatan komunikatif memang memungkinkan anak untuk dapat membaca dan menulis dengan baik, belajar dengan orang lain, menggunakan media, menerima informasi dan menyampaikan informasi. Hal ini senada dengan pendapat Brown (dalam Ololube, dkk., 2010:3) bahwa pendekatan komunikatif digunakan mengembangkan keterampilan membaca dan menulis yang dibutuhkan untuk memastikan kepercayaan siswa dalam membaca, merangkum, menerjemahkan, berdiskusi dan berdebat, dengan menggunakan elemen-elemen yang ditemui dalam berbagai situasi untuk membuat bahasa lebih cair dan manipulasi bahasa lebih lancar. Penerapan pembelajaran menggunakan pendekatan komunikatif berbasis talking stick diawali dengan penyajian suatu dialog singkat oleh guru terkait materi pembelajaran yang dikemas dalam suatu cerita, kemudian anak bermain menggunakan tongkat yang disertai praktik lisan terkait dengan materi pembelajaran. Pembacaan cerita dan bermain baik digunakan untuk perkembangan anak usia dini khusunya untuk kemampuan literasi dini. Hal ini didukung oleh hasil penelitian Permatasari, dkk. (2017) yang menyatakan teknik bercerita dapat meningkatkan kemampuan literasi dini anak.

Berbeda dengan pendekatan komunikatif berbasis talking stick, pendekatan konservatif diterapkan dengan metode ceramah dan demonstrasi (Gora dan Sunarto, 2010:6). Diawal pembelajaran guru menjelaskan materi pembelajaran dengan cara ceramah. Langkah berikutnya yaitu, guru memberikan contoh di papan tulis terkait tugas-tugas yang akan dikerjakan anak. Hal ini menegaskan bahwa pembelajaran konservatif mengkondisikan anak hanya untuk menerima pembelajaran yang diberikan guru, tidak mencari konsep dari sebuah pembelajaran. Metode ceramah yang sering dilakukan guru juga kurang cocok dengan tingkah laku kemampuan anak yang masih kecil, karena taraf berpikir anak masih berada dalam taraf yang kurang konkret (Sagala dalam Taniredja, dkk., 2015:47).

Berdasarkan penelitian yang telah dilakukan, pendekatan komunikatif berbasis talking stick memberikan hasil yang positif terhadap kemampuan literasi dini. Hal ini didukung dari hasil uji hipotesis pada pretest dan post-test di kelompok eksperimen, dengan hasil $t_{\text {hitung }}$ lebih besar dari $t_{\text {tabel}}$, yaitu $18,312>2,000$. Hasil tersebut menunjukkan bahwa terdapat perbedaan nilai pre-test dan post-test dikelompok eksperimen. Perbedaan nilai tersebut terjadi karena pembelajaran saat pemberian pre-test dan post-test pada kelompok eksperimen berbeda. Pembelajaran pada pre-test tidak diterapkan menggunakan pendekatan komunikatif berbasis talking stick, namun lebih kepada pendekatan konservatif. Sementara pada saat post-test diterapkan pembelajaran menggunakan pendekatan 
komunikatif berbasis talking stick. Mukhlis (dalam Kompasiana, 2017) menyatakan bahwa salah satu cara untuk mengembangkan literasi dini adalah membaca dengan keras dan banyak berbicara. Neuman, dkk. (dalam Seefeldt \& Barbara, 2008:336) juga menyatakan bahwa salah satu cara untuk melaksanakan baca tulis adalah menikmati yang sedang dibacakan dan menuturkan kembali ceritacerita naratif. Hal ini sejalan dengan pembelajaran menggunakan pendekatan komunikatif berbasis talking stick yang didasarkan pada tujuan membaca dan diarahkan pada penggunaan bahasa dalam kehidupan sehari-hari (Rahim, 2007:32). Pembelajaran yang menggunakan pendekatan komunikatif berbasis talking stick merupakan salah satu cara untuk meningkatkan kemampuan literasi dini anak.

Pada kelompok kontrol terjadi hal yang berbeda dengan kelompok eksperimen. Merujuk pada hasil uji hipotesis pre-test dan post-test kelompok kontrol diperoleh nilai yang tidak jauh berbeda. Hasil uji hipotesis menunjukkan bahwa terdapat perbedaan kemampuan literasi dini anak pada pre-test dan post-test di kelompok kontrol, dengan hasil $t_{\text {hitung }}$ lebih besar dari $t_{\text {tabel }}$, yaitu $4,139>2,021$. Hal ini didukung dari nilai ratarata pre-test dan post-test kelompok kontrol yang mengalami peningkatan. Nilai rata-rata pre-test diperoleh hasil sebesar 27,27 yang termasuk kategori sangat rendah, sedangkan nilai rata-rata post-test diperoleh hasil sebesar 32,32 yang termasuk pada kategori rendah. Nilai pada pre-test dan post-test kelompok kontrol memang mengalami peningkatan nilai skor, namun peningkatan nilai ini tidak tinggi hanya 3-10 dari skor awal. Berbeda dengan nilai pada kelompok eksperimen yang mengalami peningkatan hingga 2 kali lipat dari hasil skor awal. Peningkatan nilai pada kelompok kontrol ini tidak dapat dipungkiri terjadi, karena pada proses pembelajaran anak mendapatkan pengetahuan-pengetahuan yang baru. Pengetahuan baru yang diperoleh anak dapat mempengaruhi pengetahuan anak terkait dengan kemampuan literasi dini seperti, mengenal huruf dan membuat asosiasi bunyi huruf.
Pembelajaran pendekatan konservatif pada kelas kontrol tidak memberikan pengaruh yang besar terhadap kemampuan literasi dini anak, meskipun mengalami peningkatan nilai. Hal ini terjadi karena memang pembelajaran pendekatan konservatif cenderung pada pembelajaran yang berpusat pada guru. Berpusat pada guru yang dimaksudkan adalah gurulah yang harus menjadi pusat dalam pembelajaran dan siswa ditempatkan sebagai objek belajar (Parwati dalam Ramdhani, 2014:5). Anak hanya dilibatkan pada awal penjelasan namun guru melihat hasil pekerjaan anak tanpa menanyakan apakah anak sudah memahami kegiatan dan apa yang diperoleh anak dari kegiatan tersebut. Kegiatan yang menyamaratakan kemampuan anak, mengakibatkan motivasi belajar anak rendah. Penggunaan pendekatan konservatif juga kurang sesuai dengan ciri khas dari pembelajaran untuk literasi dini, yaitu agar anak jangan merasa sedang belajar.

Berdasarkan temuan-temuan dalam penelitian ini, maka dapat dinyatakan pembelajaran pendekatan komunikatif berbasis talking stick memiliki keunggulan dibandingkan dengan pendekatan konservatif dalam hal mengembangkan kemampuan literasi dini anak.

\section{PENUTUP}

Berdasarkan pemaparan di atas, dapat disimpulkan bahwa terdapat perbedaan yang signifikan kemampuan literasi dini anak, antara anak yang mendapat pembelajaran menggunakan pendekatan komunikatif berbasis talking stick dengan anak yang mendapat pembelajaran menggunakan pendekatan konservatif pada anak kelompok B Taman Kanak-kanak Gugus Melati Kecamatan Denpasar Utara Tahun Pelajaran 2017/2018. Hal ini dapat dilihat berdasarkan hasil pengujian hipotesis dengan menggunakan uji-t diperoleh $t_{\text {hitung }}$ sebesar 12,597. Sedangkan $t_{\text {tabel }}$ dengan taraf signifikan $5 \%, d k=48$ diperoleh hasil sebesar 2,021. Ditinjau dari hasil hipotesis tersebut, maka $t_{\text {hitung }}$ lebih besar dari $t_{\text {tabel }}$ $\left(t_{\text {hitung }}>t_{\text {tabel }}\right)$, dengan demikian $\mathrm{H}_{0}$ ditolak dan $\mathrm{H}_{\mathrm{A}}$ diterima. Artinya terdapat perbedaan secara signifikan kemampuan literasi dini 
anak, antara anak yang mendapat pembelajaran menggunakan pendekatan komunikatif berbasis talking stick dengan anak yang mendapat pembelajaran menggunakan pendekatan konservatif pada anak kelompok B Taman Kanak-kanak Gugus Melati Kecamatan Denpasar Utara tahun pelajaran $2017 / 2018$.

Adapun saran yang diajukan adalah siswa di Taman Kanak-kanak agar lebih aktif dalam mengikuti pembelajaran dan terus mengembangkan pemahamannya dengan membangun pengetahuannya sendiri melalui pengalaman sehingga dapat meningkatkan kemampuannya khususnya kemampuan literasi dini. Guru di Taman Kanak-kanak agar lebih berinovasi dalam pembelajaran dengan menerapkan model maupun metode yang sesuai dengan karakteristik anak. Kepala Sekolah di Taman Kanak-kanak agar selalu berusaha memfasilitasi rekan-rekan guru lainnya agar mampu menggunakan berbagai macam pendekatan atau metode pembelajaran yang lebih bervariasi di dalam proses pembelajaran sehingga kemampuan anak meningkat. Peneliti lain agar memperhatikan kendala yang dialami dalam pelaksanaan pembelajaran pendekatan komunikatif khususnya dalam kemampuan literasi dini untuk penyempurnaan penelitian yang akan dilaksanakan.

\section{DAFTAR RUJUKAN}

Ambara, Didith Pramunditya, dkk. 2014. Asessmen Anak Usia Dini. Yogyakarta: Graha IImu.

Antara, News. 2014, 03 November. "Psikolog: Stimulasi Kemampuan Literasi Sejak Dini Penting". Tersedia pada https: //www.antaranews.com/berita/ 462239/psikolog-stimulasikemampuan-literasi-sejak-dinipenting (diakses tanggal 05 April 2018)

Kompasiana. 2017. "Melihat Kualitas Literasi Pendidikan Anak Usia Dini". Tersedia pada https://www.Kompasiana.com/ak
Antara, Putu Aditya. 2017. "Fonem Anak: Desain Pemerolehan Bahasa Pertama". Purwadita, Volume 1, Nomor 1 (hlm 51).

Christie, James F. \& Kathleen A. Roskos. 2013. "Play's Potential in Early Literacy Development". Tersedia pada http://www.childencyclopedia.com/play/according -experts/plays-potential-earlyliteracy-development (diakses tanggal 20 Juli 2018).

CNN, Indonesia. 2017, 10 September. "Mengapa Literasi di Indonesia Sangat Terendah". Tersedia pada https://student.cnnindonesia.com/ edukasi /20170910122629-445240706/ mengapa-literasi-diindonesia-sangat terendah/ (diakses tanggal 05 April 2018)

Department of Education and Child Development. 2013. Emergent Literacy Investing Early for Exponential Outcomes. Publishing: Save the Children Us.

Direktorat Pendidikan Anak Usia Dini. 2010. Pengembangan Konsep Pengetahuan Bahasa. Jakarta: Kementrian Pendidikan Nasional.

Gora, Winastwan \& Sunarto. 2010. Pakematik: Strategi Pembelajaran Inovatif Berbasis TIK. Jakarta: PT. Elex Media Komputindo.

Huda, Miftahul. 2013. Model-Model Pengajaran dan Pembelajaran. Yogyakarta: Pustaka Pelajar.

Izzaty, Rita Eka. 2014. Perilaku Anak Prasekolah. Jakarta:PT Elex Media Komputindo. hmadmukhlis27/59dded1dadbe2f 12527caa02/ melihat - kualitas literasi - pendidikan-anak-usiadini (diakses tanggal 05 April 2018). 
Konstantellou, Eva, dkk. 2009. "The Promise of Clay's Theory of Literacy Processing: Training: Literacy Lessons Intervention Specialist". Tersedia pada https://www.oakland.edu/Assets/ Oakland/readingrecovery/filesanddocuments/JRR_9.1_Konstan tellou_Lose.pdf (diakses tanggal 20 Februari 2018).

Nurdin, Rizal Syadid. 2012. Studi Komparatif Penerapan Model Pembelajaran Kooperatif Tipe GI Dengan Konvensional Pada Pembelajaran IImu Statistika Di SMK 1 Cilaku. Skripsi (tidak diterbitkan) Universitas Pendidikan Indonesia.

Ololube, Nwachukwu Prince, dkk. 2010. "Communicative Approach As A Tool For Relating Reading And Writing Skills In Early Childhood Education" Discourse and Communication for Sustainable Education, Volume 1.

Permatasari, Andalusia N, dkk. 2017. "Literasi Dini Dengan Teknik Bercerita". FamilyEdu, Volume III, Nomor 1.

Rafli, Zainal \& Ninuk Lustiyanti. 2016. Teori Pembelajaran Bahasa. Yogyakarta: Garudhawaca.

Rahim, Farida. 2007. Pengajaran Membaca di Sekolah Dasar. Jakarta: Bumi Aksara.

Seefeldt, Carol \& Wasik, Barbara A. 2008. Pendidikan Anak Usia Dini, Alih Bahasa Oleh Pius Nasar. Jakarta : Indeks.

Setyosari, Punaji. 2016. Metode Penelitian Pendidikan dan Pengembangan. Jakarta: Prenadamedia Group.

Sugiyono. 2017. Metode Penelitian Kuantitatif, Kualitatif, dan R\&D. Bandung : Alfabeta.
Taniredja, Tukiran, dkk. 2011. Model-Model Pembelajaran Inovatif dan Efektif. Bandung: Alfabeta. 